\title{
IMPACT OF CONSERVATION TILLAGE UNDER ORGANIC MULCHES ON THE REPRODUCTIVE EFFICACY AND YIELD OF QUALITY PROTEIN MAIZE
}

\author{
M. A. H. Khan ${ }^{1}$ and M. R. Parvej ${ }^{2}$
}

\begin{abstract}
The present study was carried out to evaluate the efficacy of conservation tillage under organic mulches on the reproductive developments and production potentials of Quality Protein Maize (QPM) cv. Pozarica during the period from November 2007 to April 2008. The study included tillage and zero tillage conditions and four indigenous mulches viz. water hyacinth, rice straw, rice husk and ash. All the mulches significantly modified microclimatic parameters in both tillage and zero tillage conditions. However, under non-tilth condition water hyacinth and rice straw mulches reduced the maximum soil temperature at $5 \mathrm{~cm}$ depth by $3.5-4.2^{\circ} \mathrm{C}$ and $2.4-2.7^{\circ} \mathrm{C}$, respectively at $14: 00 \mathrm{hrs}$ and raised the minimum temperature by $1.5-2.3^{\circ} \mathrm{C}$ and $1.2-1.4^{\circ} \mathrm{C}$ at 06:00 hrs. The water retentive capacity of the mulched soil under zero tillage condition was higher at all the stages of plant growth and ranked in the order of water hyacinth>rice straw>rice husk>ash>control. The reproductive developments in mulched plants were advanced by about 1 to 10 days. Mulching practices also enhanced the number of ears plant ${ }^{-1}$, ear height, length and diameter, tassel length, number of seed rows ear ${ }^{-1}$ and seeds row ${ }^{-1}$, 1000-grains weight, weight of rachis ear ${ }^{-1}$, grain yield and higher harvest index (HI). The grain yield of mulched plants notably water hyacinth was nearly

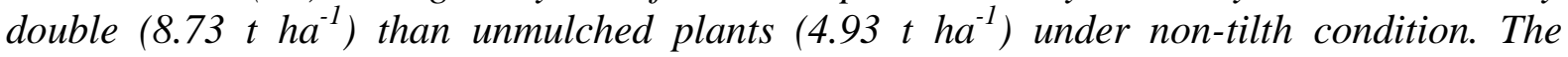
indigenous mulches especially water hyacinth and rice straw, irrespective of tilth or non-tilth conditions, appeared to be great suppressants of weed growth allowing to produce less than one third of the total biomass compared to that of control. The residual mulching effect had little or no influence on physical properties of the soil under both conditions. However, the chemical properties were favourably influenced for the follow-up crops.
\end{abstract}

Key words: Conservation tillage, organic mulches, soil moisture conservation, yield, QPM.

\section{INTRODUCTION}

Maize is the third most important cereal crop in the world after wheat and rice. Though quantitatively it is after wheat and rice, it yields the highest per unit area. The average global production of maize in 2003 was $4.47 \mathrm{t} \mathrm{ha}^{-1}$ as compared to 2.67 and $3.84 \mathrm{t} \mathrm{ha}^{-1}$ for wheat and rice, respectively (FAO, 2004). This cereal is mostly deficient in essential amino-acids; lysine and tryptophan and a vitamin, nyacin. CIMMYT has developed nutritionally improved maize containing high levels of aforesaid amino-acids and vitamin and termed as quality protein maize (QPM). Even different QPM lines have the potential to yield more than $8 \mathrm{t}$ $\mathrm{ha}^{-1}$, whereas the national average yield is only $1.06 \mathrm{t} \mathrm{ha}^{-1}$ (Rahman et al., 2002). Although the productivity of this crop is better during the dry winter season, it remains far below the world average because of the low moisture content and low atmospheric and soil temperature. During winter, rainfall is erratic and evapotranspiration is high, and only $40 \%$ of the cultivable land can be brought under irrigation (Islam and Kaul, 1986). In this situation, various types of mulching materials could be widely used as an effective cultural practice to bring a large

\footnotetext{
${ }^{1}$ Professor, Department of Crop Botany, Bangladesh Agricultural University, Mymensingh-2202, Bangladesh

${ }^{2}$ Department of Seed Science and Technology, Bangladesh Agricultural University, Mymensingh-2202, Bangladesh.
} 
area under maize cultivation.Mulching is a desirable management practice which regulates farm environment and thereby enhances crop production through regulating soil temperature (Khan, 2001), by reducing leaching and evapotranspiration (Liu et al., 2000), by increasing the soil organic matter content (Roldan et al., 2003) and by reducing nutrient loss due to run off (Smart and Bradford, 1999). On the other hand, land tilling is a common practice for crop cultivation. In Bangladesh most of the crops are usually grown after adequate soil tillage. However, with scientific bases, conservation tillage or zero-tillage techniques, as an alternative to conventional tillage is gaining popularity worldwide (Monneveux et al., 2006). Zero tillage increases the mechanical resistance and the apparent density of soil and curbs soil evaporation (Rivas et al., 1998). It has also been reported to increase total nitrogen and microbial biomass in various soils (McCarthy et al., 1995). Moreover, conservation tillage reduces the number of field operations by minimizing input costs for labour, fuel, tractors and other equipments and thus results in greater economic returns compared with conventional tillage system (Smart and Bradford, 1999).

Zero tillage system of cultivation could be more successful if other appropriate cultural practices such as mulching, crop rotations and fallow systems are applied (Franzen et al., 1993). Without any external field cover (i.e. mulching practices) zero tillage led to increase weed infestation, especially with perennial species. Conventional and continuous deep ploughing decreased soil strength, on the other hand zero tillage along with rice straw mulch (6 $\left.\mathrm{t} \mathrm{ha}^{-1}\right)$ decreased soil temperature and strengthened soil composition (Machul, 1993). Thus, zero tillage with adequate different organic mulches on the soil surface may produce yield comparable to or higher (especially in drier areas) than those of obtained from conventional tillage. However, the effectiveness of the indigenous mulches under zero tillage condition remains to be explored though the efficacy of these mulches on the growth and development of maize is well recognized. Therefore, the present study was undertaken to monitor mulch induced micro-environment and to identify effective organic mulch(es) suitable for production potentials of QPM and to observe their effects on physiochemical properties of soils under tilth and non-tilth conditions.

\section{MATERIALS AND METHODS}

\section{Experimental site and planting materials}

The present experiment was carried out at the field laboratory of the Department of Crop Botany, Bangladesh Agricultural University, Mymensingh during the period from November 2007 to April 2008. Seeds of Quality Protein Maize (QPM) cv. Pozarica (pedigree no. 8763) were used as planting material.

\section{Experimental protocol}

Land preparation for the research work was somewhat different from the traditional method. One field remained in zero tillage condition and in late October, rain water was deposited in other field by constructing 'furrows' around the field. After 3 days, weeds and stubble were removed by spade and hoe. Manures and fertilizers were applied to the plots as per recommendation of BARI (1993). The experiment was laid out in Randomized Complete Block Design (RCBD) with two different land conditions (tilth and nontilth), each comprising of five treatments and four blocks, each representing a replication. Five plots each measuring $15 \mathrm{~m} \times 10 \mathrm{~m}$ were prepared in each block. The seeds were sown $25 \mathrm{~cm}$ apart in rows at a distance of $75 \mathrm{~cm}$ between the rows. After completion of seed germination, the indigenous mulches viz. water hyacinth, rice straw, rice husk and ash at the rate of 
$10 \mathrm{t} \mathrm{ha}^{-1}$ were uniformly spread immediately over the plots assigned for the definite mulch treatment. Weeding was done manually at 40 and 70 DAS. No irrigation was applied. Appropriate measures were taken against insect-pests and diseases as and when required.

\section{Data collection}

Data were collected on microclimatic parameters such as soil temperature and moisture and on reproductive attributes namely, days to tasseling, silking and maturity, yield and yield attributes like number of ears plant ${ }^{-1}$, ear height, length and diameter, tassel length number of seed rows ear $^{-1}$ and seeds row ${ }^{-1}, 1000$-grains weight, weight of rachis ear ${ }^{-1}$, grain yield, harvest index weed growth and physiochemical properties of soil. Morpho-physiological parameters were obtained from 20 randomly selected plants of each plot.

The diurnal variation of soil temperatures was recorded on a clear sunny day with ordinary thermometer cased in copper tubes with pointed tips at hourly intervals at the depth of $5 \mathrm{~cm}$ beginning from 06:00 hrs to 17:00 hrs on 22 DAS and 80 DAS. Moisture content at $0-5 \mathrm{~cm}$ depths of the soil layers was measured by electronic soil moisture and temperature meter (Delta devices, UK) at 10 day intervals starting from 40 DAS and continued to 120 DAS. Weeds grown in $1 \mathrm{~m}^{2}$ area of unit plot were collected from mulching treatments during the weeding at 40 and 70 DAS. The weeds were oven dried at $80 \pm 2^{\circ} \mathrm{C}$ for 48 hrs and measured by an electric balance to record the total weed biomass. After one month of final harvest the analysis of the soil particle of the experimental plots was carried out by hydrometer method described by Black (1965). The textural classes were determined by using the Marshall's Triangular Co-ordinates. The $\mathrm{pH}$ of the soil sample was determined with the help of a glass electrode $\mathrm{pH}$ meter. Organic $\mathrm{C}$, total $\mathrm{N}$, available $\mathrm{P}, \mathrm{K}$ and $\mathrm{S}$ content of the soil sample was determined according to Walkley and Black (1935), Page et al. (1989), Olsen et al. (1954), Black (1965) and Page et al. (1989), respectively.

\section{Statistical analysis}

The collected data on different parameters under study were compiled and subjected to statistical analysis. Analysis of variance was calculated following the experimental design with the help of the computer package MSTAT-C (Russell, 1986). The means differences were evaluated by the Least Significant Difference (LSD) and Duncan's New Multiple Range Test (Gomez and Gomez, 1984).

\section{RESULTS AND DISCUSSION}

\section{Soil temperature}

A remarkable variation in soil temperature was observed due to non-tilth condition and mulches throughout the day (Figure 14). The greatest influence was recorded in water hyacinth mulched plants, which reduced the maximum soil temperature at 22 and 80 DAS by 4.2 and $3.5^{\circ} \mathrm{C}$ and increased the minimum temperature by 1.5 and $2.3^{\circ} \mathrm{C}$, respectively when compared to the control. The reduction of soil temperature of water hyacinth was followed by rice straw, rice husk and ash. Mulches reduced the soil temperature by day because they reflect a considerable part of incidental solar radiation. Moreover, their lower thermal conductivity prevents and decreases the amount of downward transmission of heat (Giri and Singh, 1985). On the other hand, higher temperature under mulched condition at night might be due to trapping of out going long wave radiation released by the soil (Rahman et al., 2002). Increased soil temperature accelerated the rates of leaf tip appearance, full leaf expansion and enabling the crop canopy development, more biomass production with only minimal impact on air temperature (Stone et al., 1999). 


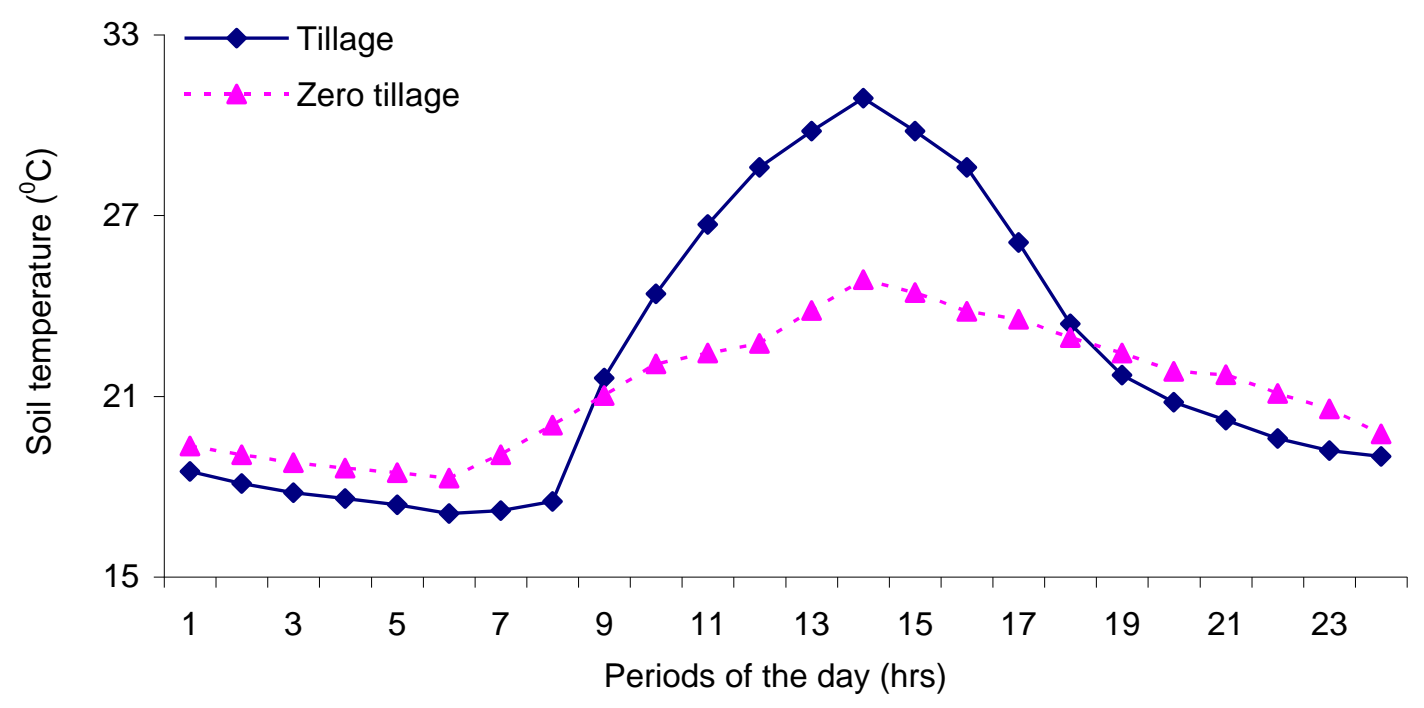

Figure 3. Diurnal fluctuation of soil temperature at $5 \mathrm{~cm}$ depth as influenced by tilth and non-tilth conditions on 20 February 2008 i.e. 80 DAS.
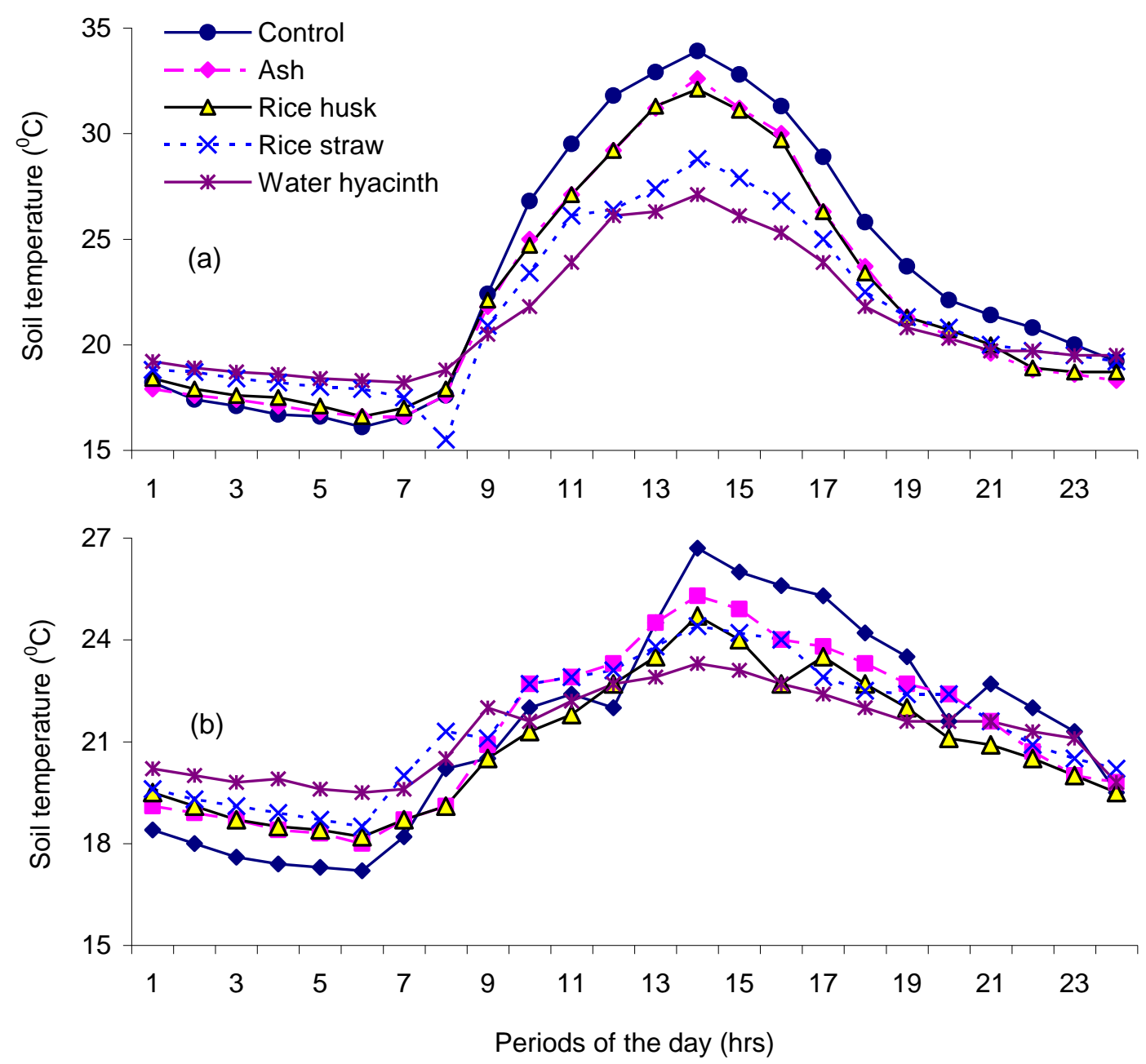

Figure 4. Diurnal fluctuation of soil temperature at $5 \mathrm{~cm}$ depth as influenced by indigenous mulches under tilth (a) and non-tilth (b) conditions on 20 February 2008 i.e. 80 DAS. 


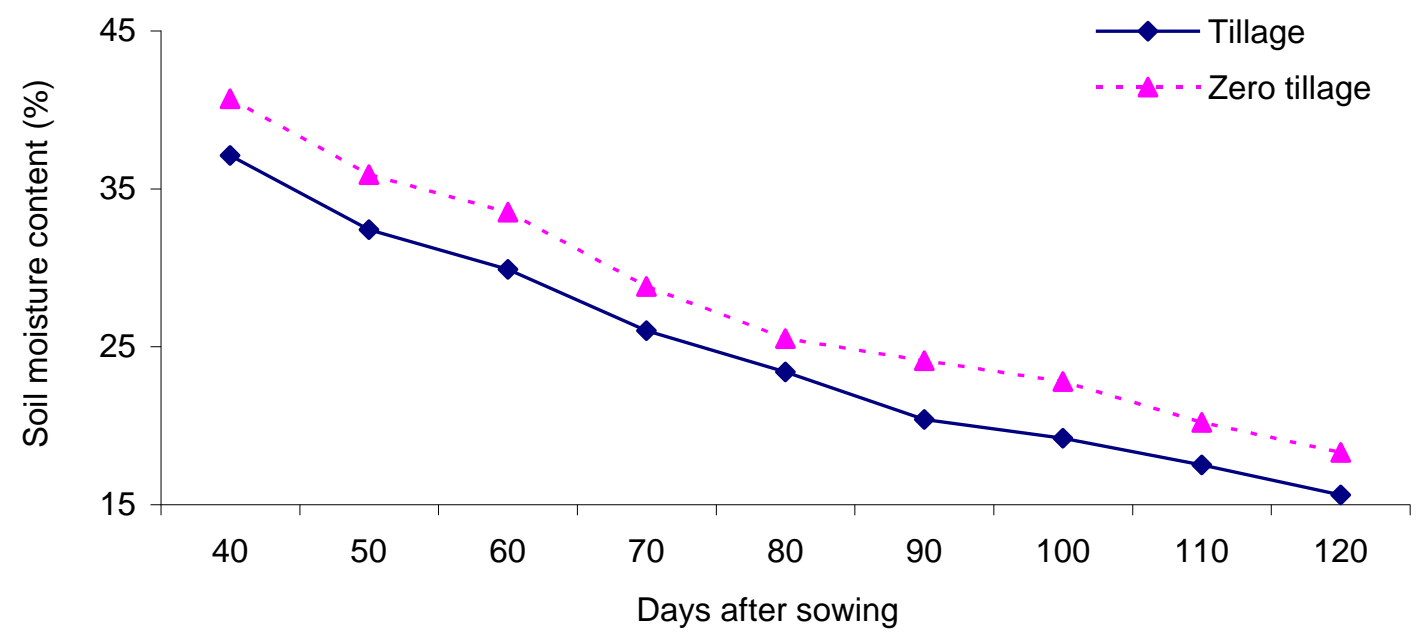

Figure 5. Soil moisture content (weight per cent) at different days after sowing as influenced by conventional and conservation tillage.
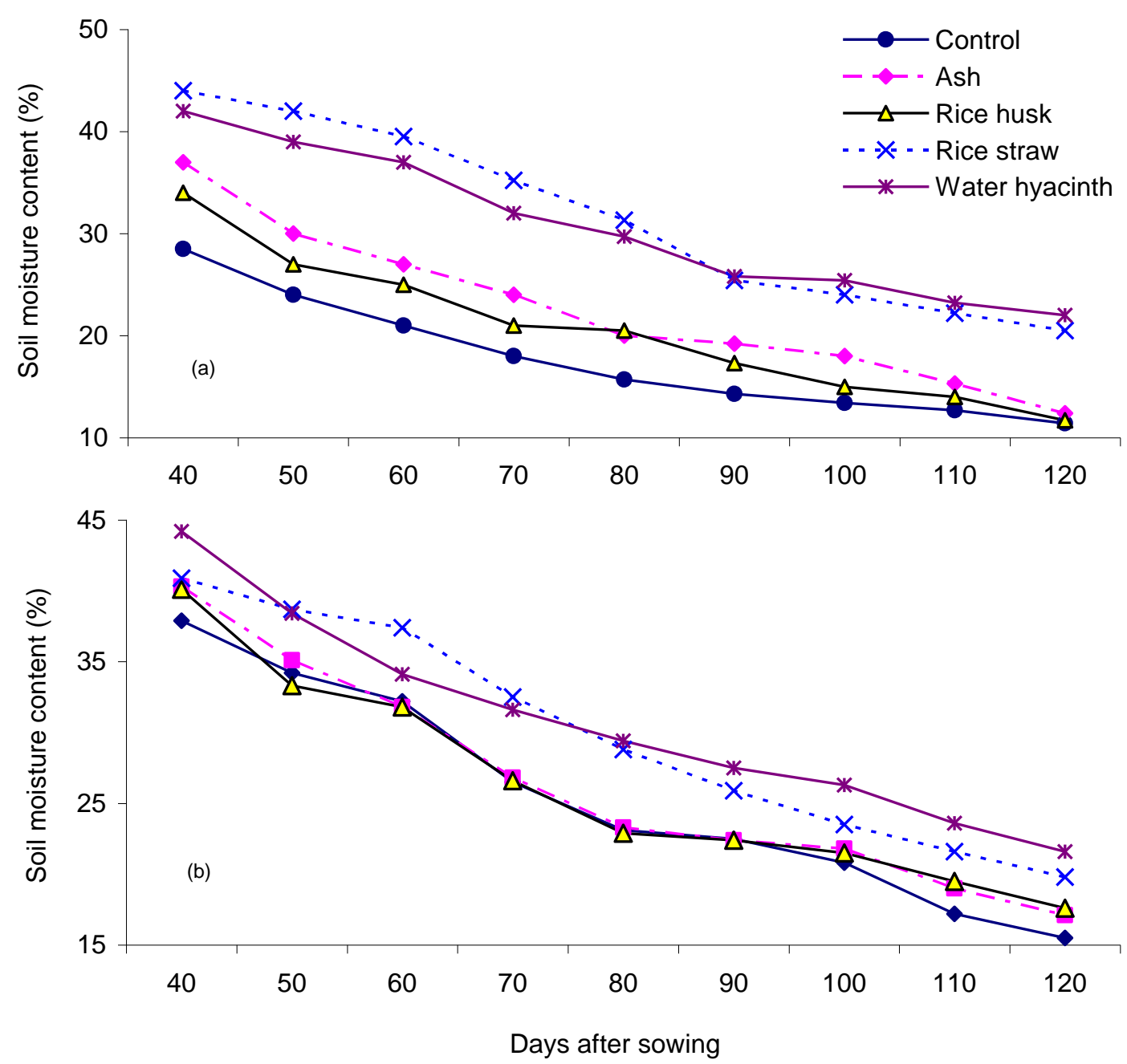

Figure 6. Soil moisture content (weight per cent) at different days after sowing as influenced by different indigenous mulches under tillage (a) and zero tillage (b) conditions. 


\section{Soil moisture content}

There were significant changes in soil moisture content with time due to non-tilth condition and application of different indigenous mulches (Figure 5 and 6). The initial higher soil moisture content at 40 DAS decreased gradually up to crop maturity. It was always higher in non-tilth than the tilth conditions (Figure 5). Rice straw and water hyacinth mulches contained maximum soil moisture throughout the entire period of growth when compared to other mulches and control under both conditions (Figure 6). The performance of rice husk and ash in retaining soil moisture was intermediate. The effectiveness of mulches with regards to soil moisture content was in the order of rice straw $>$ water hyacinth $>$ rice husk $>$ ash $>$ control.

During the growth stages from 40 to 90 DAS soil moisture content decreased since there was no rainfall (Weather Yard, 2008). Rice straw and water hyacinth mulches retained maximum soil moisture in this period probably due to reduced evaporation (Cui et al., 1998), transmissivity (Mbagwu, 1990), plant transpiration (Shekour, et al., 1987) and increased hydrolic conductivity (Schoningh, 1985), water infiltration (Sutrisno et al., 1995) and water holding capacity (Xu et al., 1988). However, under zero tillage condition, the dry-land lost soil moisture due to higher evapotranspiraion. But no-tillage with adequate organic mulch on the soil surface conserved soil moisture which was comparable to or higher than the conventional tillage system (Gicheru et al., 1998). In addition, the accumulation of leaf litter on the surface layer of compacted soils caused a reduction of evapotranspiration and thus, soil moisture was conserved (Vidhana Arachchi and Liyanage, 2003).

\section{Days to tasseling, silking and maturity}

Zero tillage condition and all the mulches significantly decreased the number of days required to tasseling, silking and maturity as compared to control (Table 1). Irrespective of mulching, the date of tasseling, silking and maturity were advanced by about 4, 2 and 6 days, respectively under non-tilth condition. However, under tilth condition, advancing was more for silking, but lower for maturity and similar for tasseling in rice straw and water hyacinth mulched plants than under non-tilth condition. The influences of rice husk and ash mulches were intermediate in this respect. The interaction effects between tilth and nontilth conditions were insignificant for all the reproductive characters.

The number of days to tasseling and silking of QPM was reduced possibly due to their earlier emergence and favourable soil temperature under water hyacinth and rice straw mulches (Madsen, 1992). Mulched treatments also maintained significantly greater plant available water (PAW) compared to the bare soil until near anthesis and after anthesis which helped earlier initiation of tassel and silk (Tolk et al., 1999). However, the earlier maturity in water hyacinth and rice straw treated plants was due to the higher minimum soil temperature caused by the mulches (Rahman et al., 2002).

\section{Yield contributing attributes}

Yield contributing attributes such as number of ears plant ${ }^{-1}$, ear height, length and diameter, tassel length, number of seed rows ear ${ }^{-1}$ and seeds row $^{-1}, 1000-$ grains weight and weight of rachis ear ${ }^{-1}$ were significantly affected by zero tillage and different mulches (Table 2). However, under zero tillage condition most yield attributes were significantly increased with the water hyacinth and rice straw mulches compared to rice husk, ash and control than tillage condition. There was no significant variation in number of ears plant $^{-1}$ between tilth and non-tilth conditions. But tilth and non-tilth 
conditions were interacted insignificant for all the yield contributing characters.

Mulch induces yield improvements in maize plant (Ma and Han, 1995). Different researchers found that cultivation of maize under minimum tillage or zero tillage along with various mulches did not significantly reduce the yield and yield contributing attributes (Tolk et al., 1999), which were similar to our findings.

Table 01: Effect of tilth conditions and indigenous mulches on reproductive characters of QPM

\begin{tabular}{lccc}
\hline Treatments & Days to tasseling & Days to silking & Days to maturity \\
\hline Tillage & $73.64 \mathrm{~b}$ & $82.46 \mathrm{~b}$ & $131.94 \mathrm{~b}$ \\
Zero Tillage & $76.05 \mathrm{a}$ & $83.96 \mathrm{a}$ & $138.30 \mathrm{a}$ \\
LSD $_{(0.01)}$ & 0.88 & 0.67 & 1.23 \\
\hline Tillage $\times$ Mulches & & & $136.1 \mathrm{a}$ \\
Control & $78.2 \mathrm{a}$ & $87.0 \mathrm{a}$ & $132.8 \mathrm{~b}$ \\
Ash & $75.6 \mathrm{~b}$ & $85.3 \mathrm{~b}$ & $132.3 \mathrm{~b}$ \\
Rice husk & $75.3 \mathrm{~b}$ & $85.1 \mathrm{~b}$ & $129.6 \mathrm{c}$ \\
Rice straw & $69.8 \mathrm{c}$ & $77.8 \mathrm{c}$ & $128.9 \mathrm{~d}$ \\
Water hyacinth & $69.3 \mathrm{c}$ & $77.1 \mathrm{~d}$ & 0.60 \\
LSD $(0.01)$ & 0.85 & 0.67 & $144.1 \mathrm{a}$ \\
\hline Zero Tillage $\times$ Mulches & & & $142.0 \mathrm{~b}$ \\
Control & $81.28 \mathrm{a}$ & $92.10 \mathrm{a}$ & $141.4 \mathrm{~b}$ \\
Ash & $80.35 \mathrm{a}$ & $91.28 \mathrm{ab}$ & $133.1 \mathrm{c}$ \\
Rice husk & $75.20 \mathrm{~b}$ & $86.07 \mathrm{c}$ & $132.3 \mathrm{c}$ \\
Rice straw & $72.28 \mathrm{c}$ & $85.07 \mathrm{c}$ & 1.05 \\
Water hyacinth & $71.52 \mathrm{c}$ & $83.30 \mathrm{c}$ & 0.68 \\
LSD $(0.01)$ & 0.97 & $\mathrm{c}$ &
\end{tabular}

Figures with same letter in a column are statistically similar at $1 \%$ level of significant

Table 02: Yield and yield contributing attributes of QPM as influenced by conservation tillage and indigenous mulches

\begin{tabular}{|c|c|c|c|c|c|c|c|c|c|c|}
\hline Treatment & $\begin{array}{l}\text { No. of } \\
\text { ears } \\
\text { plant }^{-1}\end{array}$ & $\begin{array}{l}\text { Ear } \\
\text { height } \\
(\mathrm{cm})\end{array}$ & $\begin{array}{l}\text { Ear } \\
\text { length } \\
(\mathrm{cm})\end{array}$ & $\begin{array}{l}\text { Ear } \\
\text { diameter } \\
(\mathrm{cm})\end{array}$ & $\begin{array}{l}\text { Tassel } \\
\text { length } \\
(\mathrm{cm})\end{array}$ & $\begin{array}{l}\text { No. of } \\
\text { seed rows } \\
\text { ear }^{-1}\end{array}$ & $\begin{array}{l}\text { No. of } \\
\text { seeds } \\
\text { row }^{-1}\end{array}$ & $\begin{array}{l}1000 \\
\text { seeds } \\
\text { wt. (g) }\end{array}$ & $\begin{array}{l}\text { Wt. of } \\
\operatorname{rachis}^{-1} \\
\operatorname{ear}^{-1}(\mathrm{~g})\end{array}$ & $\begin{array}{l}\text { Grain } \\
\text { yield } \\
\left(\mathrm{t} \mathrm{ha}^{-1}\right)\end{array}$ \\
\hline Tillage & 1.06 & $57.5 b$ & $15.1 \mathrm{a}$ & $4.48 \mathrm{a}$ & $46.24 b$ & $13.78 \mathrm{a}$ & $28.15 \mathrm{a}$ & $219.82 \mathrm{a}$ & $19.88 \mathrm{a}$ & $4.63 a$ \\
\hline Zero Tillage & 1.09 & $65.63 a$ & $16.3 b$ & $5.24 b$ & $51.33 \mathrm{a}$ & $14.40 \mathrm{~b}$ & $29.94 b$ & $335.75 b$ & $35.12 b$ & $7.10 \mathrm{~b}$ \\
\hline $\operatorname{LSD}_{(0.01)}$ & NS & 4.20 & 1.19 & 0.76 & 4.39 & 1.06 & 1.06 & 18.6 & 8.05 & 2.38 \\
\hline \multicolumn{11}{|c|}{ Tillage $\times$ Mulches } \\
\hline Control & $1.0 \mathrm{c}$ & $51.1 \mathrm{c}$ & $12.0 \mathrm{c}$ & $3.9 \mathrm{c}$ & $42.9 \mathrm{c}$ & $12.6 b$ & $22.5 c$ & $189.5 \mathrm{c}$ & $14.9 \mathrm{c}$ & $2.96 \mathrm{e}$ \\
\hline Ash & $1.0 \mathrm{c}$ & $53.6 \mathrm{c}$ & $13.8 b$ & $4.41 b$ & $45.2 \mathrm{bc}$ & $13.0 \mathrm{~b}$ & $26.26 b$ & $221.9 b$ & $18.0 \mathrm{~b}$ & $3.76 \mathrm{~d}$ \\
\hline Rice husk & $1.0 \mathrm{c}$ & $54.6 \mathrm{c}$ & $14.5 b$ & $4.39 b$ & $46.0 \mathrm{bc}$ & $13.6 b$ & $27.5 b$ & $218.0 \mathrm{~b}$ & $19.4 b$ & $4.23 c$ \\
\hline Rice straw & $1.1 b$ & $59.4 b$ & $17.1 \mathrm{a}$ & 4.69ab & $47.7 \mathrm{ab}$ & $14.7 \mathrm{a}$ & $31.5 \mathrm{a}$ & $229.2 \mathrm{ab}$ & $23.0 \mathrm{a}$ & $5.54 \mathrm{~b}$ \\
\hline Water hyacinth & $1.2 \mathrm{a}$ & $68.8 \mathrm{a}$ & $18.1 \mathrm{a}$ & $4.94 \mathrm{a}$ & $49.4 \mathrm{a}$ & $15.0 \mathrm{a}$ & $33.0 \mathrm{a}$ & $240.5 \mathrm{a}$ & $24.1 \mathrm{a}$ & $6.67 \mathrm{a}$ \\
\hline $\operatorname{LSD}_{(0.01)}$ & 0.06 & 3.87 & 1.17 & 0.36 & 3.10 & 1.06 & 1.99 & 15.6 & 1.4 & 0.32 \\
\hline \multicolumn{11}{|c|}{ Zero Tillage $\times$ Mulches } \\
\hline Control & $1.0 \mathrm{~d}$ & $37.03 d$ & $14.50 \mathrm{~b}$ & $5.09 \mathrm{~d}$ & $43.30 \mathrm{c}$ & $13.00 \mathrm{~b}$ & $25.25 b$ & $316.62 \mathrm{c}$ & $28.6 \mathrm{~d}$ & $4.93 \mathrm{~d}$ \\
\hline Ash & $1.0 \mathrm{~d}$ & $48.70 \mathrm{c}$ & $15.05 b$ & $5.17 \mathrm{c}$ & $46.80 \mathrm{c}$ & $14.00 \mathrm{~b}$ & $27.50 \mathrm{ab}$ & $332.97 b$ & $32.4 \mathrm{c}$ & $6.55 c$ \\
\hline Rice husk & $1.04 \mathrm{c}$ & $70.55 b$ & $17.00 \mathrm{a}$ & $5.27 \mathrm{~b}$ & $52.75 b$ & $14.50 \mathrm{ab}$ & $30.25 \mathrm{ab}$ & $340.25 a$ & $37.2 b$ & $7.46 \mathrm{~b}$ \\
\hline Rice straw & $1.15 b$ & $86.70 \mathrm{a}$ & $17.00 \mathrm{a}$ & $5.32 \mathrm{a}$ & $57.60 \mathrm{a}$ & $15.00 \mathrm{ab}$ & $32.70 \mathrm{a}$ & $342.30 \mathrm{a}$ & $38.2 b$ & $7.85 b$ \\
\hline Water hyacinth & $1.25 \mathrm{a}$ & $89.18 \mathrm{a}$ & $17.97 \mathrm{a}$ & $5.35 \mathrm{a}$ & $58.20 \mathrm{a}$ & $15.50 \mathrm{a}$ & $34.00 \mathrm{a}$ & $346.60 \mathrm{a}$ & $39.3 \mathrm{a}$ & $8.73 a$ \\
\hline $\operatorname{LSD}_{(0.01)}$ & 0.07 & 3.92 & 1.21 & 0.42 & 3.24 & 1.18 & 2.95 & 7.38 & 1.01 & 0.48 \\
\hline
\end{tabular}

Figures with same letter in a column are statistically similar at $1 \%$ level of significant 


\section{Grain yield}

Zero tillage and all the mulching treatments had a positive effect on grain yield when compared to tillage conditions and the control, respectively (Table 2). Plants under non-tilth condition gave a higher grain yield $\left(7.10 \mathrm{t} \mathrm{ha}^{-1}\right)$ when compared to plants in tilth plots $\left(4.63 \mathrm{t} \mathrm{ha}^{-}\right.$ $\left.{ }^{1}\right)$. The highest grain yield $\left(8.73 \mathrm{tha}^{-1}\right)$ was obtained from water hyacinth mulched plants followed by rice straw, rice husk, ash and control under non-tilth condition while it was $6.67 \mathrm{t} \mathrm{ha}^{-1}$ under tilth condition. There was no significant difference between rice straw and rice husk in promoting the grain yield under non-tilth conditions (Table 2).Water hyacinth and rice straw mulches generated favourable soil temperature and soil moisture conditions which in turn increased the dry matter accumulation in plant (Rahman et al., 2002). Grain yield and total dry matter production in cereals were positively related. Straw mulch induced yield improvement in maize as stated by Crutchfield (1985). The different dry land crops like maize, sorghum, soyabeans and mung beans sown under no-tillage with adequate vegetative mulch produced grain yields comparable with or higher than (especially in drier season) those obtained from conventional tillage (Tolk et al., 1999).

\section{Harvest index (HI)}

Tilth conditions and different mulches had a significant effect on HI (Table 3). It was higher in non-tilth condition than in the tilth condition. The highest HI was obtained from water hyacinth mulched plants (0.618) under non-tilth condition while it was (0.478) under tilth conditions. However, the interaction between tilth and non-tilth conditions had insignificant influence on the HI.

The HI of cereals depends on grain yield (Bhatia, 1975) and biological yield (Kramer, 1979). The HI of water hyacinth and rice straw treated plants increased possibly as a consequence of their higher gain yield and biological yield. Grain yield increment was significantly correlated with HI. Increased HI resulted from increased crop yield was being probably because of improved partitioning of dry matter to the cob as stated by Planiappan (1985).

\section{Weed growth}

The impact of different indigenous mulches at 40 and 70 DAS under tillage and zero tillage condition was found to be significant in terms of weed biomass production (Table 3 ). Under tilth condition the maximum weed biomass was obtained $\left(55.14 \mathrm{gm}^{-2}\right)$ at 40 DAS and the lowest in non-tilth condition $\left(41.32 \mathrm{gm}^{-2}\right)$ at 70 DAS (Table 3). Besides, all the mulches controlled the weed growth at both stages compared to the bare plot. However, water hyacinth and rice straw mulches suppressed the weed growth greatly by inducing higher growth rate of maize plants. The interaction effects between tilth and non-tilth conditions were insignificant for weed growth.

Different indigenous mulches such as water hyacinth, rice straw, rice husk and ash reduce the emergence and survival of weeds in maize (Mohler and Calloway, 1992). The greater suppression of weed biomass was observed in water hyacinth and rice straw treated plots probably due to the little or no transmission of solar radiation through the mulches (Rahman et al., 2002). The present findings are in agreement with Machul (1993).

\section{Aftermath mulching effects on physiochemical soil properties}

\section{Physical properties of soil:}

Different mulch treatments did not play any significant role in changing the physical properties such as sand, silt and clay contents in soil. Generally the organic mulches are much slower than the chemical fertilizer in respect of nutrient 
release in soil. Even the organic mulches may leave residual effects for about 4-5 years (Tilander, 1993). This fact may be the probable cause for the non significant impact on physical properties of soil in the present investigation.

\section{Chemical properties of soil:}

Aftermath changes in chemical properties of soil due to application of different indigenous mulches on maize crop as presented in Table 4. Ash mulch increased soil $\mathrm{pH}$ significantly over all other mulch treatments, while the rice straw mulch decreased it when compared to the control. The highest organic carbon (1.19\%) was observed under water hyacinth mulch followed by rice husk $(1.08 \%)$ and rice straw $(1.07 \%)$, due to high decomposition rate of water hyacinth. The accumulation of nitrogen from water hyacinth and straw mulches appeared to be $0.127 \%$ and
$0.116 \%$, respectively and they occupied superior position over rest of the mulches. Although, they were significantly different from each other, their accumulation rate over control treatment was recognizable. However, all the treatments showed more or less similar results in case of phosphorus accumulation but only the ash treatment differed significantly from the others. The result also indicated that rice straw and ash mulches significantly increased available potassium over control treatment, whereas the rice husk and water hyacinth mulches showed a decreasing effect. A significant variation was also found in case of sulphur contents due to mulching. Although, the water hyacinth mulch ranked first (19.15 ppm), the rice straw and ash mulches did not differ significantly from the rice husk in term of sulphur.

Table 03: Effect of tilth conditions and indigenous mulches on $\mathrm{HI}$ and weed growth

\begin{tabular}{|c|c|c|c|}
\hline \multirow[t]{2}{*}{ Treatments } & \multirow{2}{*}{$\begin{array}{l}\text { Harvest index } \\
\text { (HI) }\end{array}$} & \multicolumn{2}{|c|}{ Weed growth $\left(\mathrm{gm}^{-2}\right)$} \\
\hline & & $40 \mathrm{DAS}$ & $70 \mathrm{DAS}$ \\
\hline Tillage & $0.379 \mathrm{~b}$ & $55.14 \mathrm{a}$ & $53.86 \mathrm{a}$ \\
\hline Zero Tillage & $0.522 \mathrm{a}$ & $42.34 b$ & $41.32 b$ \\
\hline $\operatorname{LSD}_{(0.01)}$ & 0.023 & 9.67 & 8.56 \\
\hline \multicolumn{4}{|c|}{ Tillage $\times$ Mulches } \\
\hline Control & $0.191 \mathrm{~d}$ & $90.4 \mathrm{a}$ & $89.6 a$ \\
\hline Ash & $0.350 \mathrm{c}$ & $69.6 b$ & $67.5 b$ \\
\hline Rice husk & $0.398 b$ & $58.5 b$ & $56.5 b$ \\
\hline Rice straw & $0.478 \mathrm{a}$ & $30.4 \mathrm{c}$ & $29.3 c$ \\
\hline Water hyacinth & $0.478 \mathrm{a}$ & $26.8 \mathrm{c}$ & $26.4 \mathrm{c}$ \\
\hline $\operatorname{LSD}_{(0.01)}$ & 0.011 & 15.86 & 11.49 \\
\hline \multicolumn{4}{|c|}{ Zero Tillage $\times$ Mulches } \\
\hline Control & $0.450 \mathrm{~d}$ & $70.3 \mathrm{a}$ & $69.1 \mathrm{a}$ \\
\hline Ash & $0.467 \mathrm{~d}$ & $49.7 b$ & $49.1 b$ \\
\hline Rice husk & $0.517 \mathrm{c}$ & $45.8 \mathrm{~b}$ & $44.5 b$ \\
\hline Rice straw & $0.557 \mathrm{~b}$ & $25.2 \mathrm{c}$ & $24.5 \mathrm{c}$ \\
\hline Water hyacinth & $0.619 \mathrm{a}$ & $20.7 \mathrm{c}$ & $19.4 \mathrm{c}$ \\
\hline $\operatorname{LSD}_{(0.01)}$ & 0.032 & 6.30 & 6.90 \\
\hline
\end{tabular}

Figures with same letter in a column are statistically similar at $1 \%$ level of significant 
Table 04: Changes in chemical properties of soil due to the aftermath effect of different indigenous mulches

\begin{tabular}{lllllll}
\hline Treatments & $\mathrm{pH}$ & $\mathrm{O} . \mathrm{C}(\%)$ & $\mathrm{N}(\%)$ & $\mathrm{P}(\mathrm{ppm})$ & $\mathrm{K}(\mathrm{ppm})$ & $\mathrm{S}(\mathrm{ppm})$ \\
\hline Control & $6.33 \mathrm{bc}$ & $1.01 \mathrm{~b}$ & $0.100 \mathrm{c}$ & $26.31 \mathrm{a}$ & $58.42 \mathrm{c}$ & $15.69 \mathrm{~b}$ \\
Ash & $6.66 \mathrm{a}$ & $1.04 \mathrm{~b}$ & $0.100 \mathrm{c}$ & $16.30 \mathrm{~b}$ & $63.52 \mathrm{a}$ & $16.57 \mathrm{~b}$ \\
Rice husk & $6.28 \mathrm{bc}$ & $1.08 \mathrm{ab}$ & $0.100 \mathrm{c}$ & $24.80 \mathrm{a}$ & $56.51 \mathrm{~d}$ & $15.16 \mathrm{~b}$ \\
Rice straw & $6.18 \mathrm{c}$ & $1.07 \mathrm{ab}$ & $0.116 \mathrm{~b}$ & $27.82 \mathrm{a}$ & $62.00 \mathrm{~b}$ & $17.19 \mathrm{ab}$ \\
Water hyacinth & $6.42 \mathrm{~b}$ & $1.19 \mathrm{a}$ & $0.127 \mathrm{a}$ & $23.03 \mathrm{a}$ & $56.67 \mathrm{~d}$ & $19.15 \mathrm{a}$ \\
LSD $_{(0.01)}$ & 0.22 & 0.13 & 0.01 & 6.22 & 4.75 & 2.22 \\
\hline
\end{tabular}

Figures with same letter in a column are statistically similar at $1 \%$ level of significant

\section{CONCLUSION}

The research concluded that zero tillage condition with water hyacinth and rice straw mulches was more efficient than other mulches and the control in respect of developmental and yield contributing attributes, which ensured the higher grain yield of QPM cv. Pozarica under the agroclimatic conditions of Bangladesh. In addition, zero tillage did not bring about a decrease in yield of QPM cv. Pozarica, rather it provided an advantage of low labour requirement and prevented crop lodging. Moreover, improved physiochemical properties of soil due indigenous mulching had added advantages on the follow-up crops. This practice with QPM may supplement nutritional deficiency of the malnourished people and a good source of poultry feed in Bangladesh.

\section{ACKNOWLEDGEMENT}

The work was carried out under the special financial support from the Ministry of Science and Information \& Communication Technology, Government of the People's Republic of Bangladesh.

\section{RERERENCES}

BARI. (1993). Fertilizer Recommendation Guide 1993. Bangladesh Agriculture Research Institute, Joydebpur; Gazipur, pp. 196-197.

Bhatia, C. R. (1975). Euphytica, 24: 789 (Cited from Donald, C.M. and Hamblin J. 1976. The biological yield and harvest index of cereals as agronomic and plant breeding criteria. Adv. Agron. 28:361-405).

Black, C. A. (1965). Methods of soil analysis. Part I and II. Amer. Soc. Agron.

Crutchfield, D. A. (1985). The effect of wheat straw mulch on weed control and corn growth. Dissertation Abst. International, B. (Sci. and Engineering), 45 (9), $2741 \mathrm{~B}$.

Cui, F. J., G. Z. Wang, Z. J. Yin, Z. Q. Zhang and X. F. Pan. (1998). The effect of minced stalk mulching on the cotton field soil. China Cottons, 25 (5), 7-9.

FAO. (2004). Production Year Book of 2003. No. 57. Food and Agriculture Organization of the United Nations, Rome.

Franzen, H., R. Lal and W. Ehlers. (1993). Tillage and mulching effects on physical properties of tropical Alfisol. Soil and Tillage Res., 28 (4), 329-346. 
Gicheru, P. T., C. K. K. Gachene and E. K. Biamah. (1998). Effects of tillage and mulching on soil moisture conservation and crop production. Applied Plant Sci., 12 (1), 5-9.

Giri, G. and R. R. Singh. (1985). Influence of straw mulch and transpiration suppressants on soil temperature, dry matter and total biomass production and nutrient uptake by dry land wheat. Indian J. Agril. Sci., 55 (4), 256-261.

Gomez, K. A. and A. A. Gomez. (1984). Statistical procedures for agricultural research. Int'1 Rice Res. Inst. John Wiley \& Sons, New York. pp. 139-240.

Islam, T. M. T. and Kaul, A. K. 1986. Prospects of maize in Bangladesh. FAO/UNDP. Dhaka, Bangladesh. pp. 1-59,109.

Khan, M. A. H. (2001). Mic;roclimatic manipulation and adaptation of quality protein maize (QPM) under dryland conditions. Final Report. BARC/ARMP funded Contract Res. Project, pp.72+2+3.

Kramer, T. (1979). Yield protein relationship in cereal varieties. Proc. Eucar. Workshop on Crop physiol. and Cereal Br. (1978). Wageningen, pp. 161-165.

Liu, Z., G. Wang, H. Y. Liu, L. Lei and Y. Wu. (2000). The effect of different mulching methods with whole maize straw in dryland on maize yield. Shanxi Agric. Sci., 28, 20-22.

Ma, Y. Q. and Q. H. Han. (1995). Effect of wheat straw mulching on the growth, development and yield of maize. Acta Agric. Boreali-Sinica, 10 (1), 106-110.

Machul, M. (1993). Possibility of applying simplified tillage in the production of maize for grain under three-year monoculture. Pamietnik Pulawaski, 102, 191-199.

Madsen, M. B. (1992). Mulching of maize with plastic. Tidsskrift for planteavl., 96 (4), 343-351.

Mbagwu, J. S. C. (1990). Mulch and tillage effects on water transmission characteristics of on ultisol and maize grain yield in S. E. Nigeria, Pedologic., 40(2), 155-168.

McCarthy, G. W., J. J. Meisinger and M. M. Jenniskens. (1995). Relationship between total$\mathrm{N}$, biomass- $\mathrm{N}$ and active- $\mathrm{N}$ in soil under different tillage and $\mathrm{N}$ fertilizer treatments. Soil Biol. Biochem., 27, 1245-1250.

Mohler, C. L. and M. B. Calloway. (1992). Effect of tillage and mulch on the emergence and survival of weeds in sweet corn. J. Appl. Ecology., 29 (1), 21-34.

Monneveux, P., E. Quillerou, C. Sanchez and J. Lopez-Cesati, (2006). Effect of zero tillage and residues conservation on continuous maize cropping in a sub-tropical environment (Mexico). Plant and Soil, 279, 95-105.

Olsen, S. R., C. V. Cole, F. S. Watanabe and L. A. Dean. (1954). Estimation of available phosphorus in soils by extraction with sodium bicarbonate. U.S. Dept. Agric., pp. 929.

Page, A. L., R. H. Miller and D. R. Keeney (ed.). (1989). Methods of soil analysis, Part-2, Amer. Soc. Agron., Inc. Soil Sci. Soc. Amer., Inc. Madison, Wiscansin, USA. pp. 152-531.

Planiappan, S. P. (1985). Cropping System in the Tropics: Principles and Management. Wiley Eastern Ltd., New Delhi.

Rahman, M. A., M. A. H. Khan and M. M. Rahman. (2002). Mulch induced morphophysiological adaptation of quality protein maize. Bangladesh J. Agric. Res., 27 (3), 329-340.

Rivas, E., M. Rodriguez and U. Manrique. (1998). Effecto de la labranza sobre las propriedades fisicas y quimicas del suelo y el rendimiento de maiz en los llanos altos del estado Monagas. Agron. Trop., 48, 157-174.

Roldan, A., F. Carabaca, M. L. Elernandez, C. Garcia, C. Sanchez-Brito, M. Velasquez and M. Tiscareno. (2003). No-tillage, crop residue additions and legume cover cropping effects on soil quality characteristics under maize in Patzcuaro watershed (Mexico). Soil Till. Res., 72, 65-73.

Russell, D. F. (1986). MSTAT-C package programme. Crop and Soil Science Department, Michigan State University, USA. 
Schoningh, E. (1985). The effects of mulch on yield and factors of soil fertility in the eastern Amanzonas region on Brazil. Giessener Beitrage Zur Entwicklungsfors-chung. 6,189.

Shekour, G. M., R. A. I. Brathwaite, and C. R. McDavid. (1987). Dry season sweet corn response to mulching and antitranspirants. Agron. J. 79 (4), 529-631.

Smart, J. R. and J. M. Bradford. (1999). Conservation tillage corn production for a semi-arid, subtropical environment. Agron. J., 91, 116-121.

Stone, P. J., I. B. Sorensen and P. D. Jamieson. (1999). Effect of soil temperature on phenology, canopy development, biomass and yield of maize in a cool temperature climate. Field Crops Res., 63 (2),169-178.

Sutrisno, M., Y. A. Arifandi, A. R. Till, Nursasongko, S. Winarso, G. J. Blair and E. T. Craswell. (1995). The role of mulches and terracing in crop production and water, soil and nutrient management in East Java, Indonesia. Soil organic matter management for sustainable agriculture: A workshop held in Ubon, Thailand. pp. 15 -21.

Tilander, Y. (1993). Effects of mulching with Azadirachta indica and Albizia lebbeck leaves on the yield of sorghum under semi-arid conditions in Burkina Faso. Agroforestry Systems, 34 (3), 277-293.

Tolk, J. A., T. A. Howell and S.R. Evett. (1999). Effect of mulch, irrigation and soil type on water use and yield of maize. Soil and Tillage Res., 50 (2), 137-147.

Vidhana Arachchi, L. P. and Liyanage M de S. (2003). Soil water content under coconut palms in sole and mixed (with nitrogen-fixing trees) stands in Sri Lanka. Agroforestry Systems. 57, 1-9.

Walkley, A. and C. A. Black. (1935). An examination of the Degtigaraeff method for determining soil organic matter and proposed modification for the cromic acid titration method. Soil Sci., 37, 29-38.

Weather Yard, (2008). Records of climatological observations (daily). November 2007 to April 2008. Weather yard, Department of Irrigation and Water Management, Bangladesh Agricultural Universitry, Mymensingh. Bangladesh.

Xu, X. Y., Y. M. Zhang, H. Xang, J. S. Hu, , X. M. Zhou, F. X. Yu and F. P. Wang. (1988). Effects of straw mulch and reduced tillage on soil fertility and crop yields. J. Soil Sci., 19 (2), 86-88. 